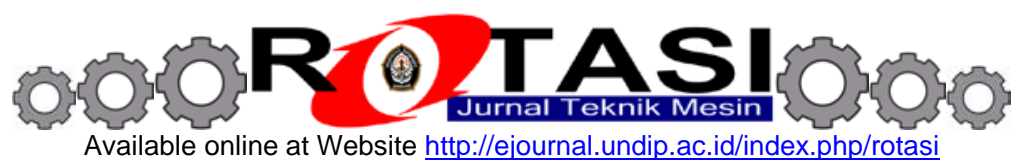

\title{
Analisa Pengeringan Secara Konveksi Butiran Teh pada Fluidized Bed Dryer Menggunakan Computational Fluid Dynamic (CFD)
}

\author{
*MSK Tony Suryo Utomo, Ghiffar Yanuar \\ Departemen Teknik Mesin, Fakultas Teknik, Universitas Diponegoro \\ Jl. Prof. Sudharto, SH., Tembalang-Semarang 50275, Telp. +62247460059 \\ *E-mail: yanuarghiffar@gmail.com
}

\begin{abstract}
Abstrak
Simulasi numerik perpindahan panas pada teh dilakukan dengan menempatkan material teh pada domain komputasi sebuah aliran eksternal. Penurunan massa pada teh dihitung secara analitik dengan menggunakan persamaan laju penurunan massa. Teh dimodelkan dengan bentuk menyerupai bola setelah dilakukan pelayuan untuk kemudian dikeringkan. Kecepatan masuk aliran udara divariasikan sesuai dengan batas kecepatan minimum dan maksimum fluidisasi pada fluidized bed dryer. Kecepatan yang divariasikan yaitu $3 \mathrm{~m} / \mathrm{s}, 5 \mathrm{~m} / \mathrm{s}$, dan $7 \mathrm{~m} / \mathrm{s}$. Temperatur masuk aliran udara juga divariasikan berdasarkan temperatur pengeringan teh untuk fluidized bed dryer yaitu $92^{\circ} \mathrm{C}, 95^{\circ} \mathrm{C}$, dan $100^{\circ} \mathrm{C}$. Model aliran yang digunakan yaitu aliran laminar dengan $\mathrm{Re}<10^{5}$ untuk aliran external. Hasil penelitian menunjukkan bahwa perpindahan panas dan perpindahan massa terjadi dengan cepat untuk material teh. Berdasarkan variasi kecepatan aliran udara dan temperatur, maka semakin tinggi kecepatan dan temperatur masuk aliran udara mengakibatkan semakin menurunnya waktu yang dibutuhkan untuk mengurangi kadar air pada teh. Waktu yang digunakan untuk menurunkan kadar air hingga 3\% berdasarkan temperatur pada kecepatan $3 \mathrm{~m} / \mathrm{s}$ secara berurutan adalah $515 \mathrm{~s}\left(92^{\circ} \mathrm{C}\right)$, $455 \mathrm{~s}\left(95^{\circ} \mathrm{C}\right)$, dan $380 \mathrm{~s}\left(100^{\circ} \mathrm{C}\right)$. Sementara pada kecepatan $5 \mathrm{~m} / \mathrm{s}$ waktu yag dibutuhkan adalah $400 \mathrm{~s}\left(92^{\circ} \mathrm{C}\right), 355 \mathrm{~s}$ $\left(95^{\circ} \mathrm{C}\right)$, dan $295 \mathrm{~s}\left(100^{\circ} \mathrm{C}\right)$ serta untuk kecepatan $7 \mathrm{~m} / \mathrm{s}$ berturut-turut $340 \mathrm{~s}\left(92^{\circ} \mathrm{C}\right), 300 \mathrm{~s}\left(95^{\circ} \mathrm{C}\right)$, dan $250 \mathrm{~s}\left(100^{\circ} \mathrm{C}\right)$. Untuk pengeringan teh lebih optimal dilakukan dengan menaikkan kececepatan masuk aliran fluida dibandingkan dengan menaikkan temperatur.
\end{abstract}

Kata kunci: Kadar air, kecepatan aliran masuk, penurunan massa, temperatur pengeringan, waktu pengeringan

\section{Pendahuluan}

Perkebunan merupakan salah satu sektor pertanian yang mempunyai peranan cukup penting dalam kegiatan perekonomian Indonesia. Indonesia merupakan salah satu negara dengan hasil perkebunan terbesar di dunia. Sektor ini berperan cukup besar dalam memberi konstribusi penyediaan lapangan kerja dan sumber devisa. Bidang usaha perkebunan terdiri dari usaha budidaya perkebunan dan usaha industri perkebunan. Usaha budidaya perkebunan adalah serangkaian kegiatan pengusahaan tanaman yang meliputi pra tanam, penanaman, pemeliharaan dan pemanenan termasuk perubahan jenis tanaman. Usaha industri perkebunan meliputi industri gula pasir dari tebu, teh hitam, dan teh hijau, kopi, kakao, karet, kelapa sawit, lada serta industri perkebunan lainnya. Teh merupakan minuman yang sudah dikenal dengan luas di Indonesia dan di dunia, sehingga meminum teh merupakan kegiatan yang sering dilakukan masyarakat Indonesia pada pagi hari maupun waktu tertentu.

Sebelum teh bisa dinikmati oleh masyarakat, tentu teh tersebut telah melalui berbagai macam proses salah satunya yaitu proses pengeringan. Pengeringan adalah pemisahan sejumlah kecil air atau zat cair dari bahan sehingga mengurangi kandungan atau sisa cairan di dalam zat padat itu sampai suatu nilai yang dikehendaki. Proses pengeringan telah dikenal manusia sejak lama. Melalui proses pengeringan berbagai hasil pertanian, perkebunan, kehutanan dan hasil laut dapat disimpan lama sehingga kehilangan pascapanen yang merugikan petani dapat dihindari.

Di Indonesia untuk mengeringkan teh dengan menggunakan mesin pengering masih terbatas pada industri menengah dan industri besar sedangkan untuk industri kecil proses pengeringan masih dilaksanakan dengan cara konvensional atau penjemuran dengan memanfaatkan panas matahari. Pengeringan buatan merupakan pengeringan yang paling efisien karena tidak tergantung pada kondisi cuaca yaitu dengan menggunakan mesin pengering dengan bahan bakar minyak, gas, batubara, maupun dengan listrik. Mesin pengering menggunakan uap panas sudah umum digunakan di negara maju, agar kondisi pengeringan dapat dikendalikan sedemikian rupa sehingga proses pengeringan tersebut dapat berjalan secara efisien, efektif dan menghasilkan produk dengan kualitas prima [1].

Pengeringan hamparan terfluidasi (fluidized bed drying) adalah salah satu proses pengeringan dengan memanfaatkan aliran udara panas dengan kecepatan tertentu yang dilewatkan menembus hamparan bahan sehingga hamparan bahan tersebut memiliki sifat seperti fluida. Jenis pengeringan menggunakan FBD ini umum dipakai di Indonesia dimana suhu masuk (inlet) yang disarankan tidak boleh terlalu rendah maupun terlalu tinggi, optimal 92-100 ${ }^{\circ} \mathrm{C}$, dan suhu keluar (outlet) $75-80^{\circ} \mathrm{C}$ [2]. 
Pada penelitian ini fluidized bed dryer akan digunakan untuk mengeringkan teh dimana teh dimodelkan secara partikel dan digulung menyerupai bola kemudian disimulasikan menggunakan software CFD. Tujuan pemodelan tersebut yaitu untuk mengetahui distribusi temperatur pada teh yang selanjutnya akan dilakukan perhitungan secara analitik untuk mendapatkan laju penguapan, waktu pengeringan, dan diketahui massa teh setelah pengeringan. Penggunaan CFD pada penelitian ini dipilih karena memiliki beberapa keuntungan salah satunya yaitu dapat menunjukkan distribusi aliran, weight losses, massa, dan perpindahan panas secara jelas. Penggunaan CFD ini akan membuat gambaran pengetahuan tentang suatu hal yang terjadi pada suatu proses atau sistem seperti fenomena aliran pada pengeringan menjadi semakin jelas. Keuntungan lain yang dapat diperoleh yaitu sangat memungkinkan untuk menganalisa parameter masukan pada pengeringan yang sesuai dengan waktu dan biaya yang lebih minim.

\section{Metode penelitian}

\subsection{Diagram Alir Penelitian}

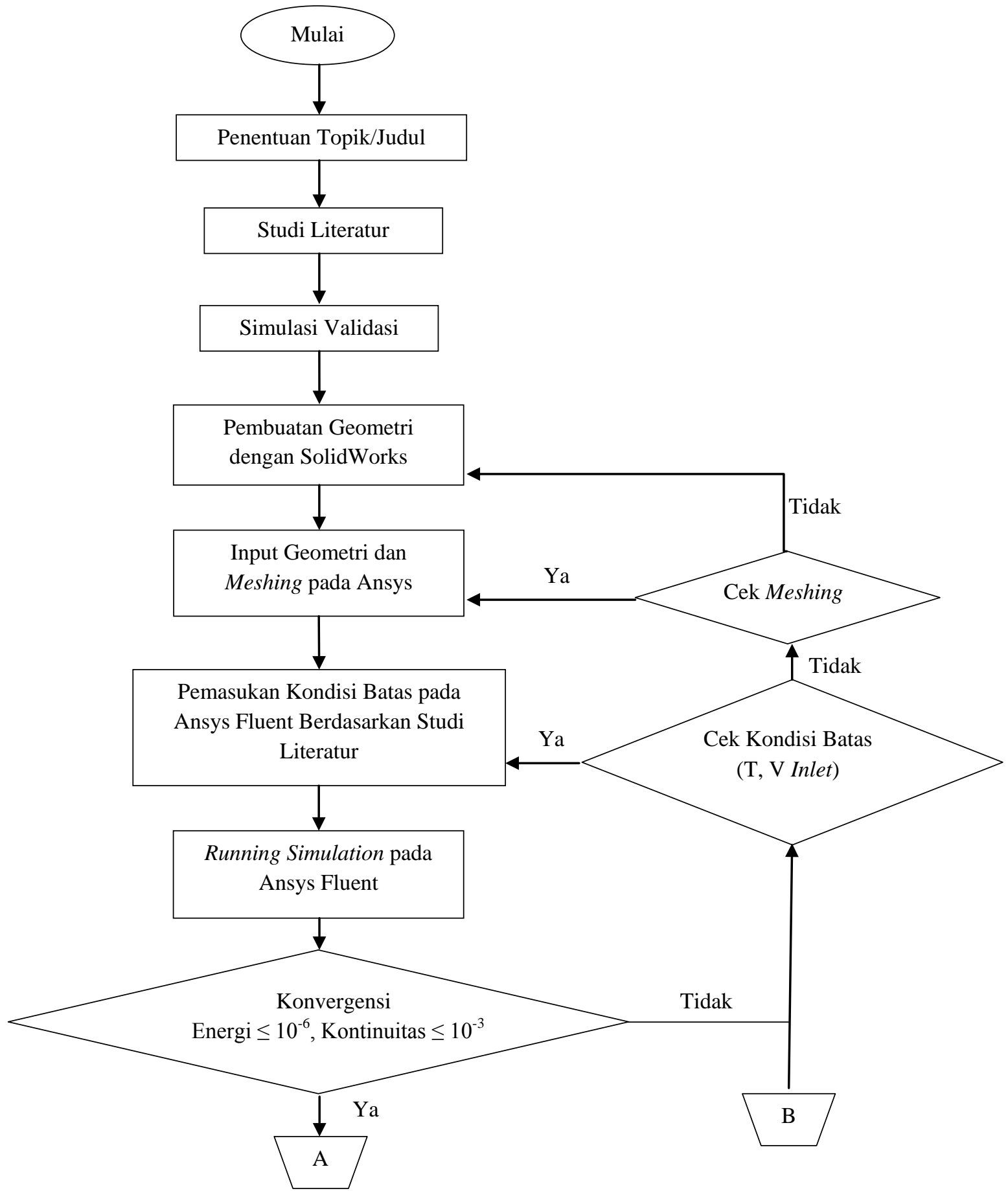

Gambar 1. Diagram Alir Penelitian dan Simulasi 


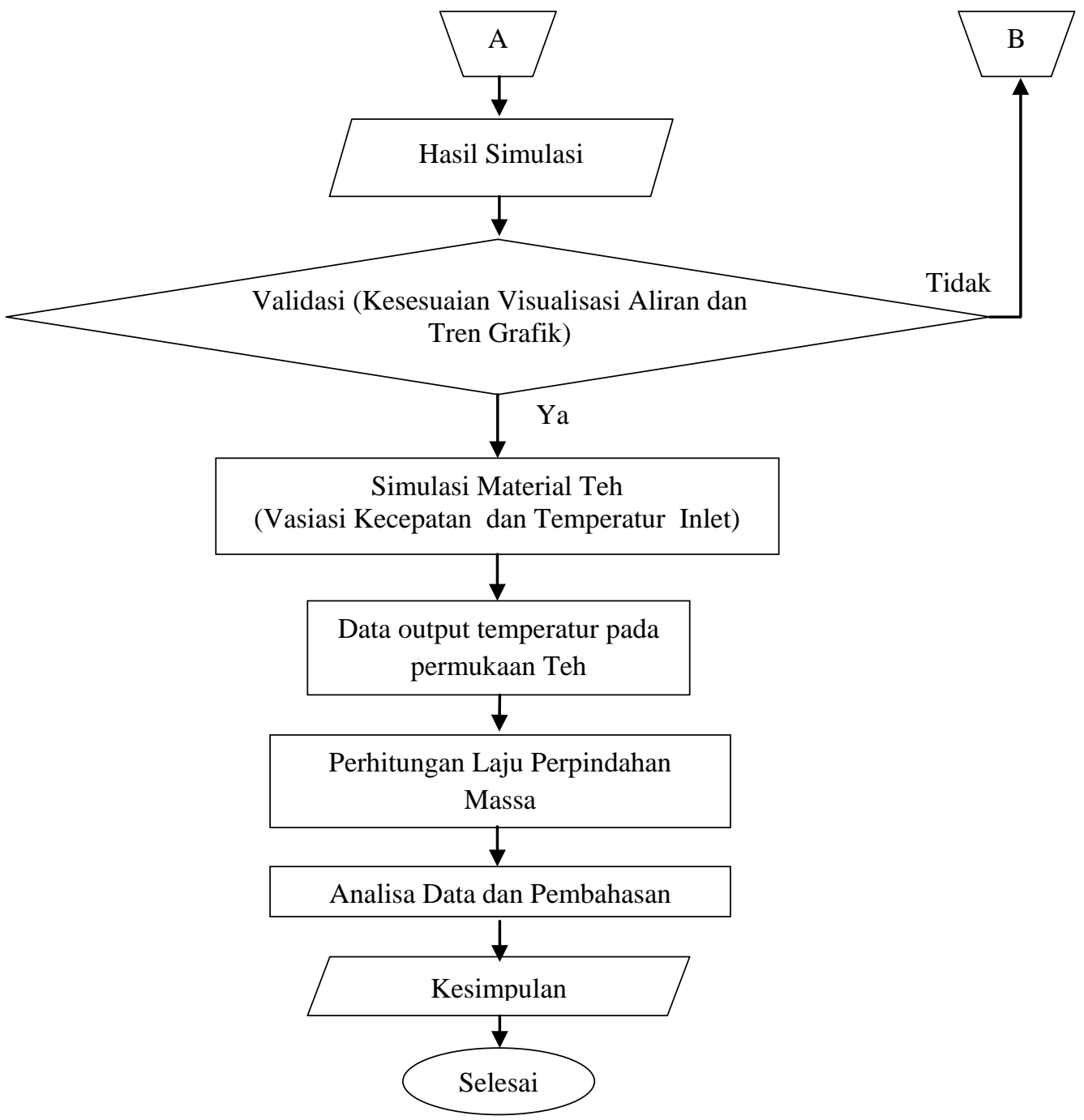

\subsection{Pemodelan}

Gambar 2. Diagram Alir Penelitian dan Simulasi Lanjutan

\subsubsection{Validasi}

Pada penelitian ini dilakukan simulasi untuk validasi yaitu simulasi pengeringan pada material kentang seperti yang pernah dilakukan oleh Atequee dkk. Pemodelan terlebih dahulu dilakukan pada material kentang yang diletakkan pada tengah dengan ukuran kentang 8x8x8 mm berbentuk kubus dan domain komputasi dengan panjang $40 \mathrm{~mm}$, lebar $10 \mathrm{~mm}$, dan tinggi $10 \mathrm{~mm}$. Pembuatan geometri dilakukan menggunakan software SolidWork 2015. Geometri teh ditunjukkan seperti pada Gambar 1.

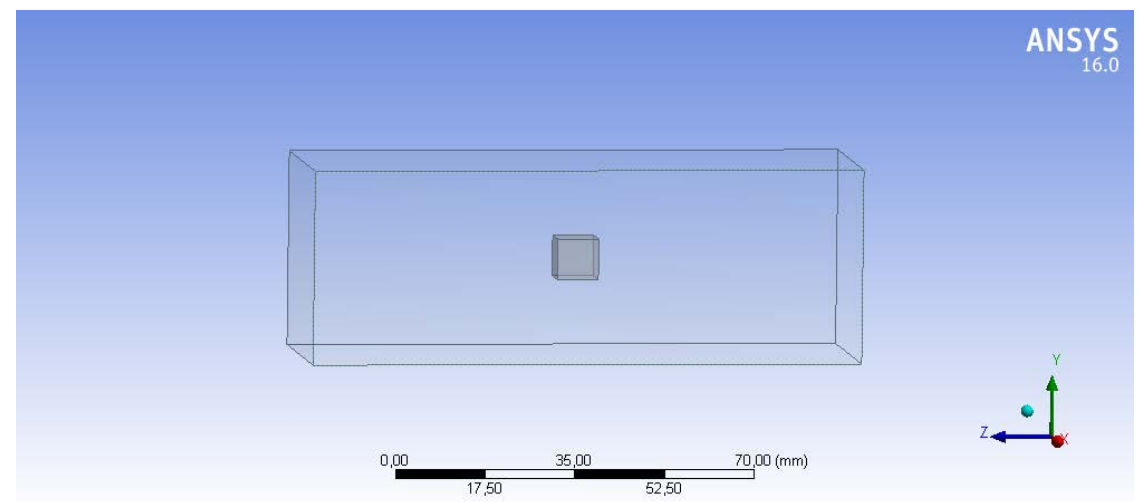

Gambar 3. Pemodelan Geometri Simulasi 
Setelah dilakukan simulasi untuk material kentang, kemudian diamati kesesuaian aliran seperti pada penelitian sebelumnya. Ateeque MD, dkk. menyatakan bahwa visualisasi aliran hasil simulasi disekitar objek kentang menunjukkan fenomena aliran dan distribusi seperti Gambar 4 [3].

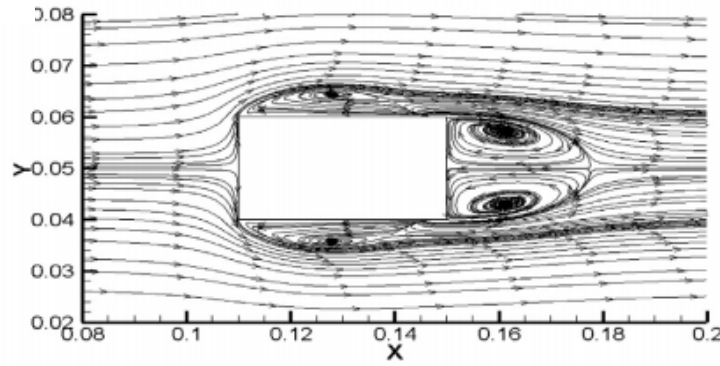

(a) Streamline

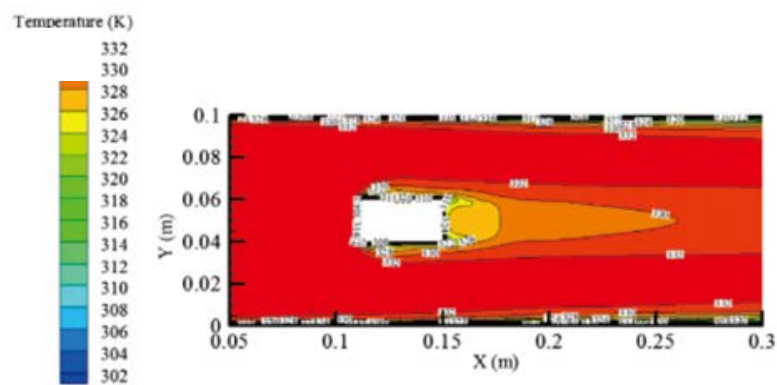

(b) Kontur Temperatur Disekitar Material

Gambar 4. Hasil Simulasi Menurut Ateeque MD, dkk.

Hasil visualisasi aliran pada penelitian ini dapat dilihat pada Gambar 5 dan 6
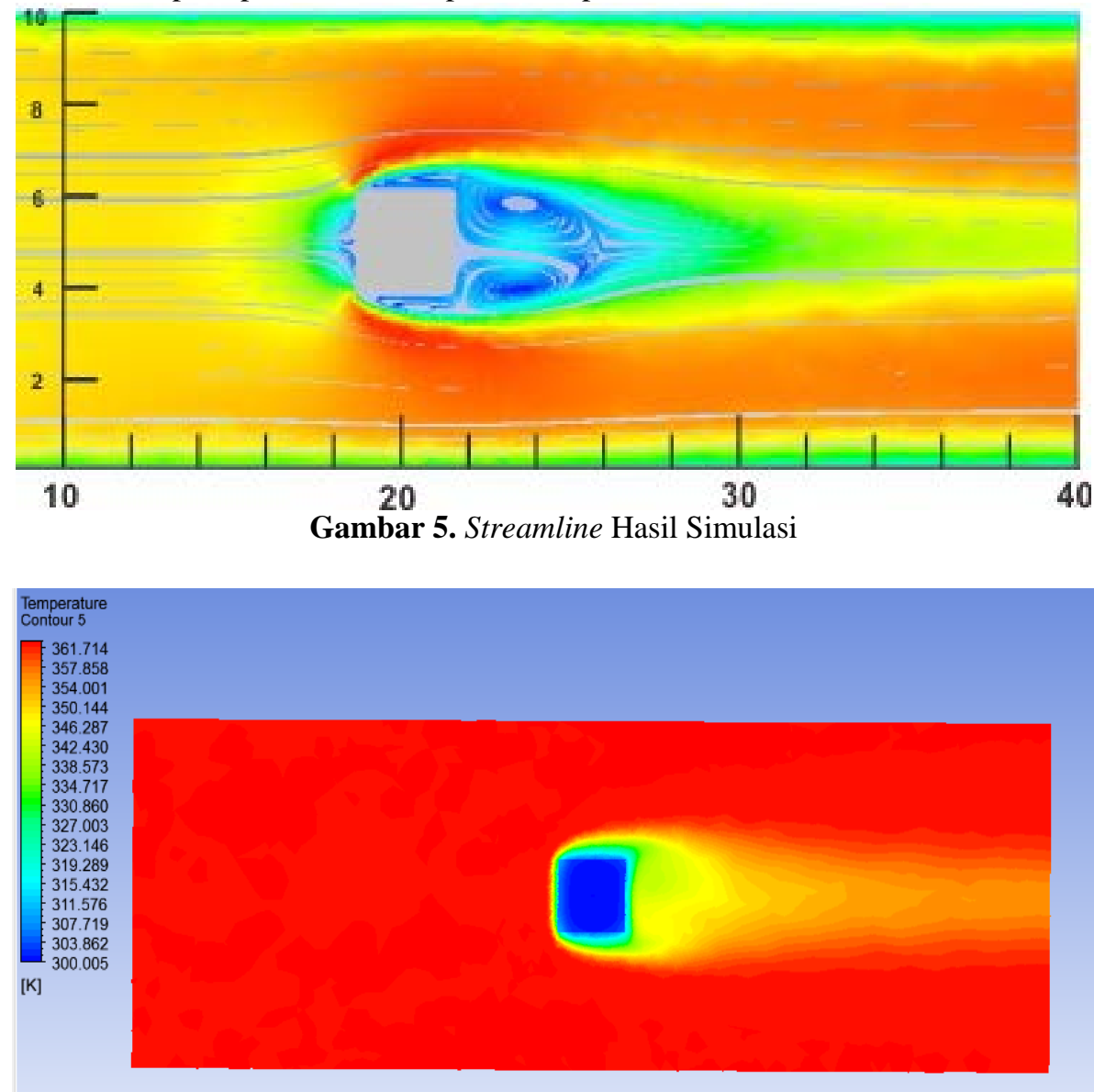

Gambar 6. Kontur Temperatur Disekitar Material

Gambar 4 sampai 6 menunjukkan kesesuaian visualisasi aliran dimana pada streamline terbentuk pusaran aliran didaerah belakang material kentang. Pada distribusi temperatur hasil simulasi juga menunjukkan kesesuaian yaitu terdapat daerah dengan temperatur yang lebih rendah pada belakang material kentang.

Selain dilakukan validasi pada visualisasi aliran, kemudian dilakukan validasi distribusi temperatur pada permukaan teh dengan penelitian yang sudah ada. Milan B. Stakic menyatakan bahwa tren kenaikan distribusi temperatur pada pengeringan kentang terjadi seperti pada Gambar 7 Dari tren tersebut dapat dilihat bahwa kenaikan temperatur terjadi pada periode awal pengeringan. Setelah terjadi kenaikan yang cukup signifikan, kemudian pengeringan akan dilanjutkan pada periode temperatur konstan yaitu setelah menit ke 50. Grafik pada Gambar 7 juga menunjukkan tren kenaikan distribusi temperatur simulasi validasi pada penelitian ini. Pada periode awal pengeringan kenaikan temperatur cukup signifikan pada menit ke 10 dan selanjutnya konstan. Pada gambar tersebut ditunjukkan 
adanya perbedaan titik konstan, hal ini disebabkan karena pada simulasi Milan B. Stakic material kentang disimulasikan secara simultan dan memiliki kandungan air awal. Sedangkan pada simulasi validasi material kentang seolah-olah sebagai benda padat kering.

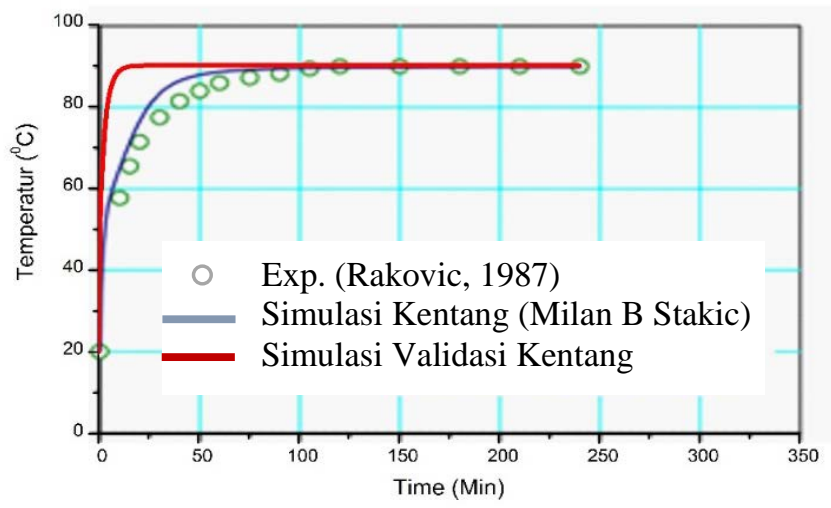

Gambar 7. Tren Kenaikan Temperatur (Milan B. Stakic) dan Simulasi Validasi [4]

Dengan adanya kesesuaian pada aliran maupun pada grafik distribusi temperatur ini dapat dikatakan bahwa metode komputasi pada simulasi kentang dapat digunakan untuk material teh. Metode komputasi yang sesuai dengan validasi dapat dilihat pada Tabel 1 .

Tabel 1. Model Komputasi Hasil Validasi

\begin{tabular}{|c|c|c|}
\hline No. & Parameter & Nilai \\
\hline 1. & $\begin{array}{l}\text { Domain Komputasi } \quad \text { (Panjang, lebar, } \\
\text { tinggi) }\end{array}$ & $40 \times 10 \times 10 \mathrm{~mm}$ \\
\hline 2. & Pengaturan General & $\begin{array}{ll}\text { - } & \text { Pressure-Based } \\
\text { - } & \text { Transient } \\
\text { - } & \text { Gravity }\end{array}$ \\
\hline 3. & Model Aliran & $\begin{array}{ll}\text { - } & \text { Laminar } \\
\text { - } & \text { Energy Equation } \\
\text { - } & \text { Species Transport }\end{array}$ \\
\hline 4. & Material & Udara : Mixture \\
\hline 5. & Kondisi Batas & $\begin{array}{ll}\text { - } & \text { Inlet : Velocity Inlet } \\
\text { - } & \text { Outlet : Pressure outlet } \\
\text { - } & \text { Dinding domain komputasi : Wall }\end{array}$ \\
\hline 6. & Monitor & $\begin{array}{l}\text { Kriteria Konvergensi } \\
-\quad \text { Continuity }: 10^{-3} \\
-\quad \text { Energy }: 10^{-6}\end{array}$ \\
\hline
\end{tabular}

\subsubsection{Pemodelan Simulasi Teh}

Setelah didapat model komputasi kemudian dilakukan simulasi pada material teh. Pemodelan dilakukan dengan proses pembentukan geometri teh dan domain komputasi simulasi. Pembuatan geometri dilakukan menggunakan software SolidWork 2015. Pemodelan geometri dibuat dengan bentuk menyerupai bola dengan diameter $7 \mathrm{~mm}$ dimana bentuk ini merupakan salah satu jenis pembentukan teh sebelum dikeringkan. Geometri teh ditunjukkan seperti pada Gambar 8 dibawah ini.

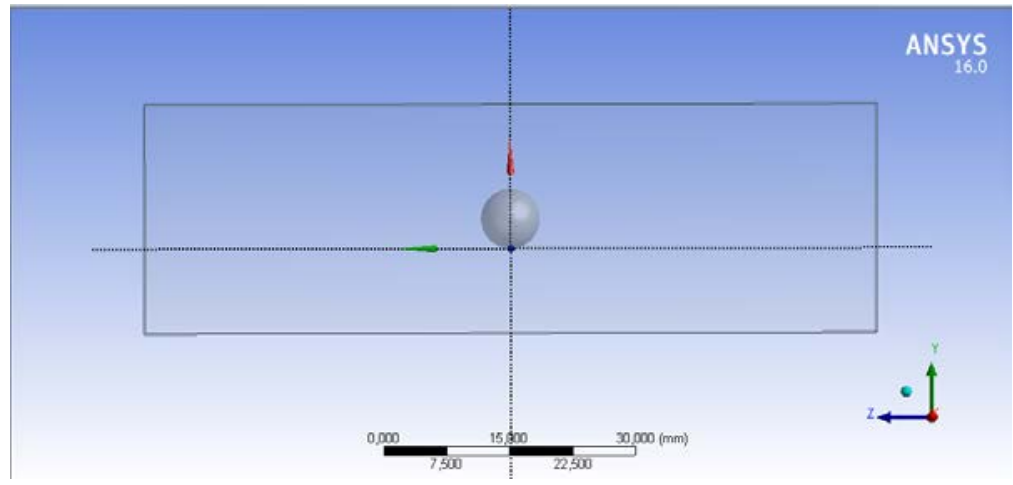

Gambar 8. Pemodelan Geometri Simulasi 
Untuk material teh yang digunakan pada simulasi dapat dilihat pada Tabel 2.

Tabel 2. Sifat Material Teh [5]

\begin{tabular}{lll}
\hline No. & Sifat & Nilai \\
\hline 1. & Panas Spesifik & $1,59-1,66 \mathrm{~kJ} / \mathrm{kg} . \mathrm{K}$ \\
2. & Konduktivitas Termal & $0,0362-0,0486 \mathrm{~W} / \mathrm{m} \cdot \mathrm{K}$ \\
3. & Densitas & $433 \mathrm{~kg} / \mathrm{m}^{3}$ \\
4. & Sphericity & 0,33 \\
5. & Diameter Partikel & $7 \mathrm{~mm}$ \\
6. & Berat Partikel & $4,3904 \mathrm{gr}$ \\
7. & Temperatur Inlet & $92-100^{0} \mathrm{C}$ \\
\hline
\end{tabular}

Untuk melakukan simulasi, terlebih dahulu ditentukan kecepatan minimum fluidisasi. pada fluidized bed dryer diperlukan kecepatan minimum dan kecepatan maksimum fluidisasi untuk menentukan titik awal terjadinya fluidisasi dan menghindari material yang dikeringkan keluar dari fluidized bed dryer. Kecepatan minimum dan maksimum fluidisasi dapat dihitung denggan persamaan [6] :

$$
U_{m f}=\frac{\left(\psi d_{p}\right)^{2}}{150 \mu}[g(\rho c-\rho g)] \frac{\varepsilon_{m f}^{3}}{1-\varepsilon_{m f}}
$$

a. $\quad$ Gravitation Term

$$
\eta=g(\rho c-\rho g)
$$

b. Porositas Minimum Fluidisasi

$$
\varepsilon_{m f}=0,586 \psi^{-0,72}\left(\frac{\mu^{2}}{\rho_{g} \eta d_{p}^{3}}\right)^{0,029}\left(\frac{\rho_{g}}{\rho_{c}}\right)^{0,21}
$$

Kecepatan maksimum fluidisasi dapat dihitung dengan persamaan :

$$
U_{t}=\left(\frac{1,78.10^{-2} \eta^{2}}{\rho_{g} \mu}\right)^{\frac{1}{3}} d_{p}
$$

\subsection{Perhitungan Penurunan Massa Teh}

\subsubsection{Koefisien Perpindahan Panas Konveksi}

Pada perpindahan panas konveksi, bilangan Nusselt digunakan untuk merumuskan koefisien perpindahan panas, dimana bilangan Nusselt dirumuskan dengan [7]:

$$
N u=\frac{h L}{k}
$$

Untuk aliran laminar $\left(\operatorname{Re}<5 \times 10^{5}\right)[12]$

$$
N u=0,664 \operatorname{Re}^{1 / 2} \operatorname{Pr}^{1 / 3} \quad \operatorname{Pr} \geq 0,6
$$

Untuk aliran turbulen $\left(5 \times 10^{5} \leq \operatorname{Re}<10^{7}\right)$

$$
N u=0,037 \operatorname{Re}^{0,7} \operatorname{Pr}^{1 / 3} \quad \operatorname{Pr} \geq 0,6
$$

\subsubsection{Koeffisien Difusi Massa}

Salah satu pasangan zat yang paling banyak aplikasinya adalah uap air dan udara. Secara khusus persamaan koefisien difusi massa pasangan ini telah dirumuskan oleh Marrero dan Mason [6]. Persamaan ini hanya berlaku untuk interval suhu $280 \mathrm{~K}<\mathrm{T}<450 \mathrm{~K}$ dan dapat dituliskan sebagai berikut :

$$
D_{\text {air-udara }}=1,87.10^{-10} \frac{T^{2,072}}{P}
$$

\subsubsection{Perpindahan Massa Konveksi}

a. Koeffisien Perpindahan Massa

Koeffisien perpindahan massa dapat dirumuskan dengan menggunakan bilangan Sherwood [7]:

$$
S h=\frac{h_{m} L}{D_{A B}}
$$


b. Bilangan Prandtl

Bilangan Prandtl yang merupakan perbandingan antara ketebalan lapis batas kecepatan dengan ketebalan lapis batas termal. Bilangan Prandtl (Pr) merupakan sifat-sifat fluida saja dan hubungan antara distribusi suhu dan distribusi kecepatan:

$$
\operatorname{Pr}=\frac{c_{p} \mu}{k}=\frac{v}{\alpha}
$$

c. Bilangan Schmidt

$$
S c=\frac{v}{D_{A B}}
$$

d. Bilangan Stanton

Penggunaan bilangan stanton diantaranya adalah untuk menentukan koefisien perpindahan kalor konveksi, menentukan koefisien gesek, menentukan tegangan gesek, dan menentukan tipe lapisan batas (termasuk laminar atau turbulen). Bilangan Stanton dapat ditulis dalam persamaan:

$$
S t=\frac{h}{\rho V c_{p}}=\frac{N u}{\operatorname{RePr}}
$$

e. Bilangan Stanton untuk Perpindahan Massa

$$
S t_{m}=\frac{h}{V}=\frac{S h}{\operatorname{Re} S c}
$$

f. Analogi Chilton Colburn

Fluida yang memiliki sifat $\operatorname{Pr} \neq \mathrm{Sc} \neq 1$, Chilton dan Colburn merumuskan persamaan sebagai berikut :

$$
S t \operatorname{Pr}^{2 / 3}=S t t_{m} c^{2 / 3}
$$

Dengan analogi diatas, maka koeffiseien perpindahan massa dan perpindahan panas dapat dihubungkan dengan persamaan dibawah ini :

$$
\frac{S t}{S t_{m}}=\left(\frac{S c}{\mathrm{Pr}}\right)^{2 / 3}
$$

Dengan mensubstitusi persamaan-persamaan sebelumnya, persamaan diatas dapat diubah menjadi :

$$
\begin{aligned}
& \frac{h}{\rho V c_{p}} \cdot \frac{V}{h_{m}}=\left(\frac{S c}{\mathrm{Pr}}\right)^{2 / 3} \\
& \frac{h}{h_{m}}=\rho c_{p}\left(\frac{S C}{\mathrm{Pr}}\right)^{2 / 3}=\rho c_{p}\left(\frac{\alpha}{D_{A B}}\right)^{2 / 3} \\
& h_{m}=\frac{h}{\rho c_{p}\left(\frac{\alpha}{D_{A B}}\right)^{2 / 3}}
\end{aligned}
$$

g. Tinjauan Perpindahan Massa

Perpindahan massa dapat dihitung menggunakan analogi perpindahan panas. Perpindahan massa dirumuskan dengan :

$$
\dot{m}_{\text {eva }}=h_{m} A\left(\rho_{s}-\rho_{\infty}\right)
$$

\section{Hasil dan pembahasan}

Pada penelitian ini dilakukan variasi 3 kecepatan inlet yang berbeda yaitu $3 \mathrm{~m} / \mathrm{s}, 5 \mathrm{~m} / \mathrm{s}$, dan $7 \mathrm{~m} / \mathrm{s}$ dimana kecepatan tersebut berada diantara kecepatan minimum dan maksimum fluidisasi $(2,483 \mathrm{~m} / \mathrm{s}-7,28 \mathrm{~m} / \mathrm{s})$. Selain itu pada simulasi ini juga dilakukan variasi temperatur inlet yaitu $92^{\circ} \mathrm{C}, 95^{\circ} \mathrm{C}$, dan $100^{\circ} \mathrm{C}$. Pada penelitian ini kemudian diamati perubahan temperatur teh yang nantinya digunakan untuk menghitung laju penurunan massa pada teh.

\subsection{Kontur Distribusi Temperatur Pada Teh}

Hasil simulasi berupa distribusi temperatur dilihat pada bagian tengah domain komputasi yaitu pada bidang YZ. Distribusi temperatur pada permukaan teh dapat dilihat pada Gambar 9. 


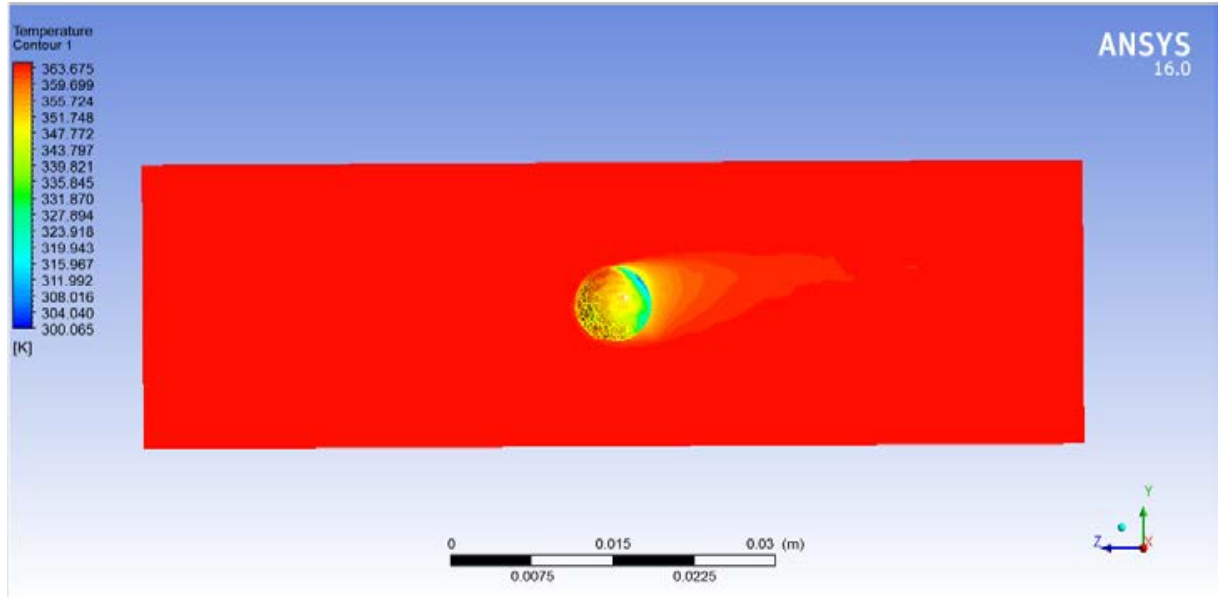

(a) Awal Pengeringan

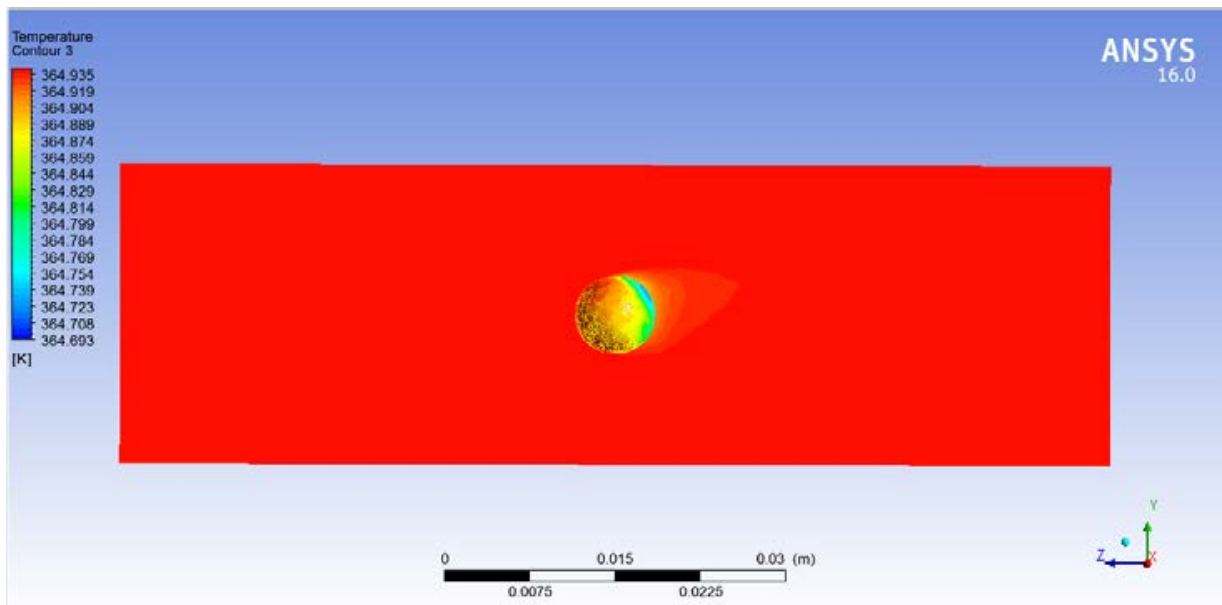

(b) Akhir Pengeringan

Gambar 9. Kontur distribusi temperatur kecepatan $7 \mathrm{~m} / \mathrm{s}$ dan temperatur inlet $92^{\circ} \mathrm{C}$

Gambar 9 menunjukkan kontur distribusi temperatur pada awal pengeringan dan akhir pengeringan. Pada awal pengeringan yaitu detik ke-5 distribusi temperatur sudah dapat dilihat. Pada bagian teh yang menghadap sisi inlet memiliki temperatur yang lebih tinggi dibandingan dengan permukaan teh yang menghadap sisi outlet untuk semua variasi kecepatan. Variasi kecepatan inlet menyebabkan perbedaan luasan daerah temperatur rendah pada bagian belakang teh atau sisi yang menghadap outlet. Semakin tinggi kecepatan inlet maka luas daerah temperatur rendah akan semakin kecil. Temperatur pada bagian dalam teh juga dapat dilihat pada Gambar 10.

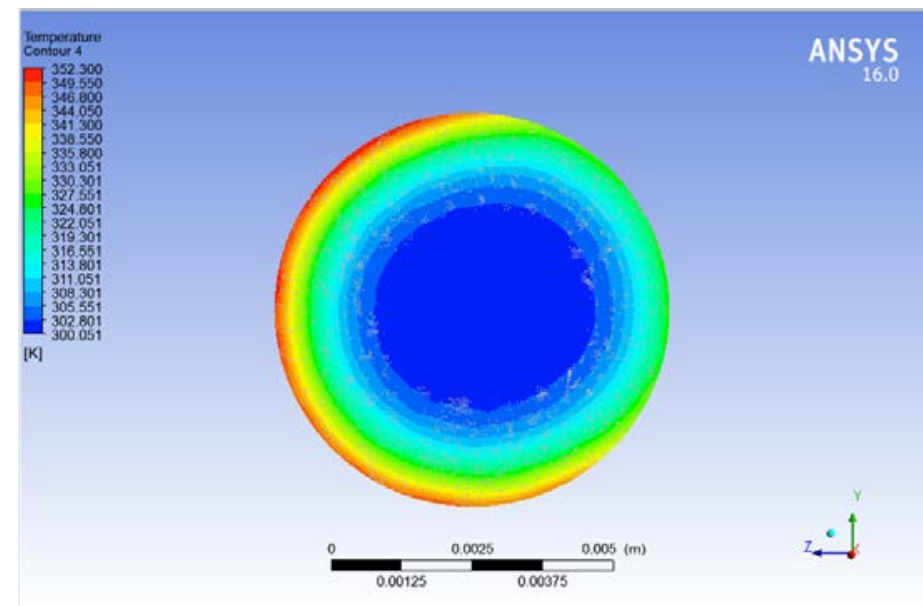

(a) Awal Pengeringan 


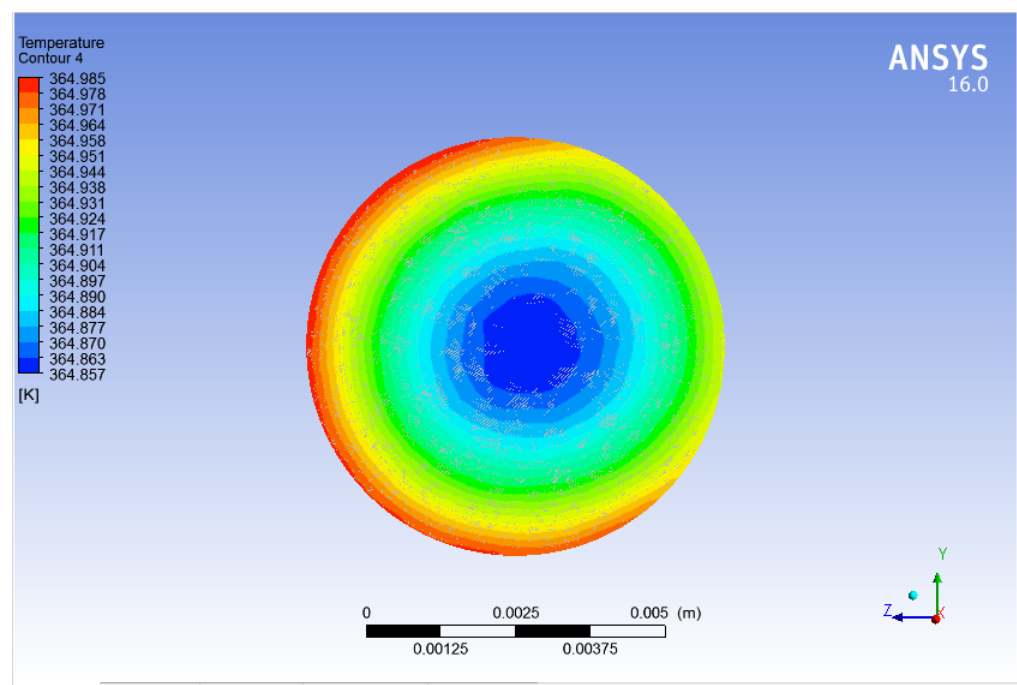

(b) Akhir Pengeringan

Gambar 10. Kontur temperatur bagian dalam kecepatan $3 \mathrm{~m} / \mathrm{s}$ dan temperatur inlet $92^{\circ} \mathrm{C}$

Pada Gambar 10 dapat dilihat bahwa temperatur teh bagian dalam pada detik ke-5 atau awal pengeringan belum mengalami kenaikan. Hal ini ditandai dengan daerah dengan temperatur rendah yang cukup luas. Temperatur tinggi hanya terjadi pada bagian luar teh. Seiring dengan waktu pengeringan, temperatur pada bagian dalam teh mulai terjadi peningkatan. Adanya variasi kecepatan inlet pada pengeringan menyebabkan daerah dengan distribusi temperatur yang berbeda untuk setiap kecepatan. Semakin tinggi kecepatan inlet maka semakin luas daerah dengan temperatur tinggi pada bagian dalam teh.

\subsection{Distribusi Temperatur}

Distribusi temperatur kemudian diplot kedalam sebuah grafik temperatur pada sumbu-y dan waktu pengeringan pada sumbu-x. Grafik kenaikan temperatur pada permukaan teh dapat dilihat pada Gambar 11.

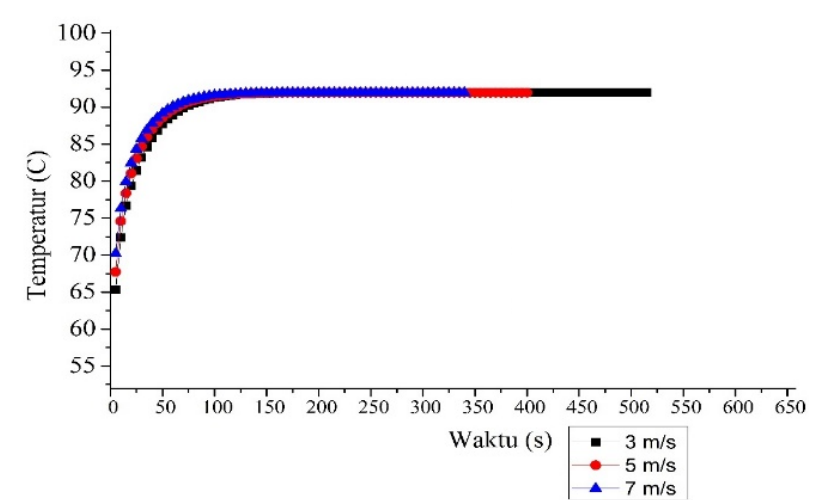

(a) Temperatur inlet $92^{\circ} \mathrm{C}$

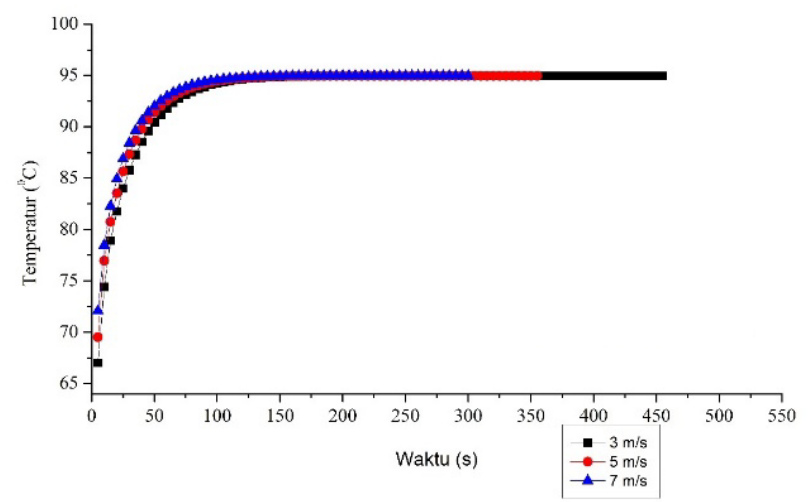

(b) Temperatur inlet $95^{\circ} \mathrm{C}$

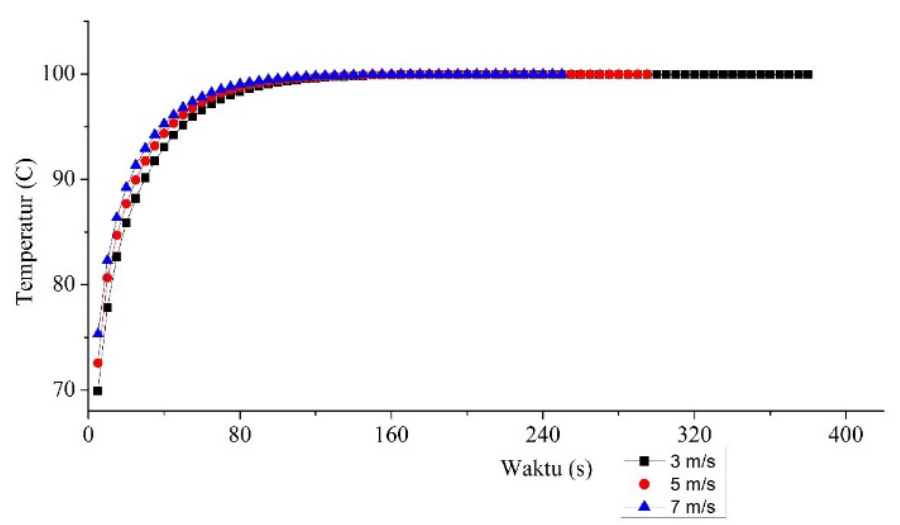

(c) Temperatur inlet $100^{\circ} \mathrm{C}$

Gambar 11. Grafik Kenaikan Temperatur 
Pada Gambar 11 dapat dilihat bahwa kenaikan temperatur terjadi sangat cepat pada awal pengeringan baik pada kecepatan inlet $3 \mathrm{~m} / \mathrm{s}, 5 \mathrm{~m} / \mathrm{s}$, maupun $7 \mathrm{~m} / \mathrm{s}$ disemua variasi temperatur inlet. Pada awal pengeringan yaitu pada detik ke 5 temperatur pada permukaan teh terus mengalami kenaikan secara signifikan. Setelah mengalami kenaikan yang signifikan, temperatur akan konstan mendekati temperatur inlet yaitu $92^{\circ} \mathrm{C}, 95^{\circ} \mathrm{C}$, dan $100^{\circ} \mathrm{C}$.

\subsection{Grafik Penurunan Massa}

Penurunan massa dapat dihitung dengan menggunakan persamaan perpindahan panas dan analogi perpindahan massa pada persamaan (3) sampai (13). Berdasarkan temperatur rata-rata pada permukaan teh dan data tambahan dari tabel sifat termofisik gas pada tekanan atmosfir maupun sifat air pada temperatur saturasi dapat dihutung penurunan massa. Dari perhitungan laju perpindahan massa kemudian dihitung massa teh sampai akhir pengeringan. Penurunan massa teh dihitung setiap 5 detik pengeringan dan kemudian diplot grafik penurunan massa terhadap waktu pengeringan.

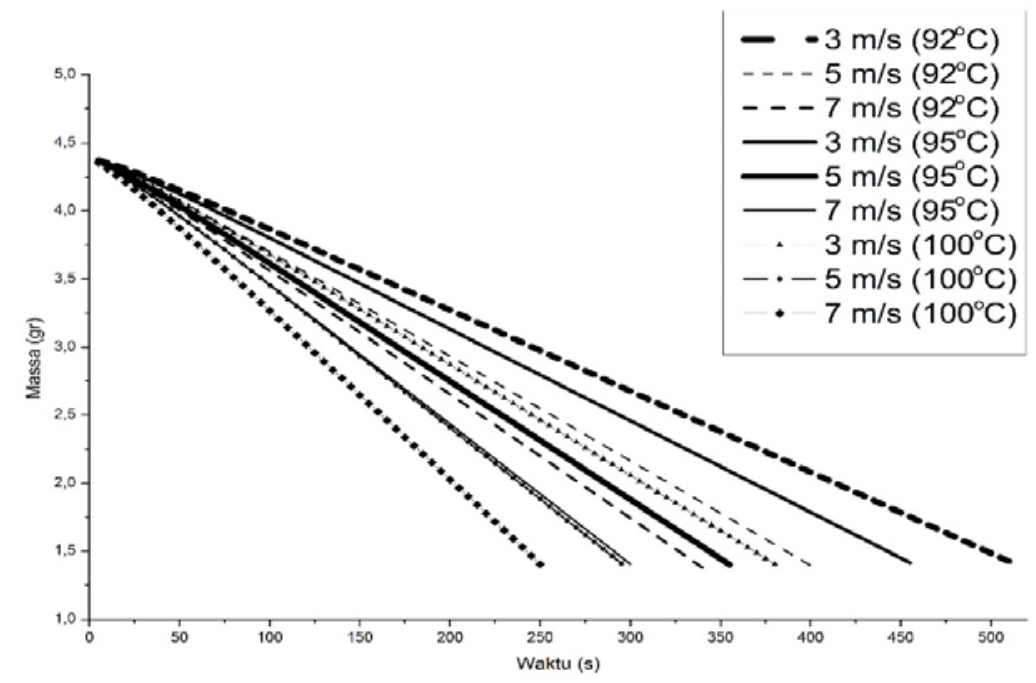

Gambar 12. Penurunan Massa Pada Teh

Pada Gambar 12 dapat dilihat grafik penurunan massa pada temperatur dan kecepatan inlet yang berbeda. Pada grafik tersebut terlihat perbedaan waktu pengeringan untuk masing-masing variasi temperatur dan kecepatan inlet. Pada awalnya teh memiliki kadar air sekitar 70\% dan berat teh basah 4,3904 gr. Setelah dilakukan pengeringan berat teh akan berkurang dikarenakan adanya penguapan air dimana kadar air teh yang baik yaitu mencapai 3\%. Kadar air pada teh harus dikurangi sebesar 67\% agar kualitas teh tetap baik. Untuk mencapai kandungan air didalam teh 3\% atau berat teh kering sekitar 1,39 gr diperlukan waktu pengeringan yang berbeda untuk setiap temperatur dan kecepatan inlet. Pada Gambar 12 dapat dilihat bahwa pengeringan paling cepat terjadi pada kondisi kecepatan dan temperatur paling maksimum. Pada temperatur $100^{\circ} \mathrm{C}$ dan kecepatan inlet $7 \mathrm{~m} / \mathrm{s}$ memiliki waktu pengeringan yang paling cepat yaitu 250 detik atau sekitar 4,16 menit. Untuk temperatur $92^{\circ} \mathrm{C}$ dan kecepatan inlet $3 \mathrm{~m} / \mathrm{s}$ memiliki waktu pengeringan yang paling lama yaitu 515 detik atau sekitar 8,15 menit. Waktu pengeringan untuk masing-masing temperatur dan kecepatan inlet dapat dilihat pada Tabel 3.

Tabel 3. Perbandingan Waktu Pengeringan

\begin{tabular}{cccc}
\hline No & Temperatur Inlet & Kecepatan Inlet & Waktu Pengeringan \\
\hline \multirow{3}{*}{1} & \multirow{2}{*}{$92^{\circ} \mathrm{C}$} & $3 \mathrm{~m} / \mathrm{s}$ & 515 detik \\
& & $5 \mathrm{~m} / \mathrm{s}$ & 400 detik \\
& \multirow{3}{*}{$95^{0} \mathrm{C}$} & $7 \mathrm{~m} / \mathrm{s}$ & 340 detik \\
& & $3 \mathrm{~m} / \mathrm{s}$ & 455 detik \\
& \multirow{2}{*}{$100^{\circ} \mathrm{C}$} & $5 \mathrm{~m} / \mathrm{s}$ & 355 detik \\
3 & & $7 \mathrm{~m} / \mathrm{s}$ & 300 detik \\
& & $3 \mathrm{~m} / \mathrm{s}$ & 380 detik \\
& & $5 \mathrm{~m} / \mathrm{s}$ & 295 detik \\
\end{tabular}

Dari Tabel 3 dapat dilihat bahwa semakin tinggi kecepatan dan temperatur inlet maka akan semakin singkat waktu pengeringan yang dibutuhkan. Waktu pengeringan paling cepat dapat dilakukan dengan menaikkan kecepatan inlet dibandingkan dengan menaikkan temperatur inlet. Hal ini dapat dilihat pada tabel bahwa waktu pengeringan pada kecepatan inlet $7 \mathrm{~m} / \mathrm{s}$ dan temperatur inlet $92^{\circ} \mathrm{C}$ masih lebih cepat yaitu sebesar 340 detik dibandingan dengan waktu pengeringan pada temperatur inlet $100^{\circ} \mathrm{C}$ dan kecepatan inlet $3 \mathrm{~m} / \mathrm{s}$ yaitu 380 detik. 


\section{Kesimpulan}

Kesimpulan yang dapat diambil dari penelitian ini yaitu pada fluidized bed dryer diperlukan kecepatan minimum $(2,483 \mathrm{~m} / \mathrm{s})$ dan kecepatan maksimum $(7,28 \mathrm{~m} / \mathrm{s})$ fluidisasi untuk menentukan titik awal terjadinya fluidisasi dan menghindari material yang dikeringkan keluar dari fluidized bed dryer. Untuk pengeringan paling cepat terjadi pada kecepatan inlet $7 \mathrm{~m} / \mathrm{s}$ dan temperatur inlet $100^{\circ} \mathrm{C}$ yaitu sebesar 250 detik sedangkan pengeringan paling lambat terjadi pada kecepatan inlet $3 \mathrm{~m} / \mathrm{s}$ dan temperatur inlet $92^{\circ} \mathrm{C}$. Selain itu semakin tinggi kecepatan dan temperatur inlet maka akan semakin singkat waktu pengeringan yang dibutuhkan. Waktu pengeringan paling cepat dapat dilakukan dengan menaikkan kecepatan inlet dibandingkan dengan menaikkan temperatur inlet.

\section{Referensi}

[1] Ompusunggu, Irwan, 2010, “Pengeringan Bubuk Teh Dengan Menggunakan Fluid Bed Dryer (FBD)”, Tugas Akhir, Universitas Sumatra Utara, Medan.

[2] Yendri, Deri. 2015, “ Mesin Pengering Pada Pengolahan Teh Hitam Orthodox Di Pt. Perkebunan Nusantara Vi (Persero) Unit Usaha Danau Kembar”,Tugas Akhir, Sumatera Barat.

[3] Stakic, Milan B, 1997 “Numerical Study on Hygroscopic Capillary-Porous Material Drying In Packed Bed”, Journal of Thermal Engineering and Energy. Yugoslavia, hal 59-70.

[4] Atequee, Md dkk, 2014 "Numerical Mdeling of convective dryng food with spatially dependend transfer coefficient in a turbulent flow field”, International Journal of Thermal Sciences, Vol. 78 145-157.

[5] http://www.tocklai.net/activities/tea-manufacture/drying/. Diakses pada 1 Juni 017 pukul 23.00 WIB.

[6] Widayati. 2010, “Fenomena dan Kecepatan Fluidisasi ( Umf )”,Tugas Akhir, UPN “Veteran”. Yogyakarta.

[7] Incropera, F.P, David P. De Witt. 1985. Fundamentals of Heat and Mass Transfer, Second Edition. John Wiley \& Sons Inc. : New York. 